\title{
Fair Competition: The Concept of Regulation in the Sharing Economy
}

\author{
Mukti FAJAR ${ }^{1}$
}

Received: August 01, 2020 Revised: October 11, 2020 Accepted: October 15, 2020

\begin{abstract}
A free-market economic system supported by the progress of the Industrial Revolution 4.0 has given birth to a sharing economy with a disruptive business model. In many ways, this business model is more effective, efficient, and makes it easy for businesses and consumers. However, because disruptive innovation is not asymmetrical with the conventional business that sustains innovation, several regulatory issues arise because it is fundamentally very different and cannot be regulated by standard law. Disruptive innovation may create chaos if it is regulated by norms that are used to regulate conventional business. This research was conducted with a normative method, which examines various theories, principles, laws and regulations to get justification for how the law should govern. The findings of this study are: competition law must be designed pragmatically so that it can keep pace with changes in business models that are rapidly changing. For this reason, it is necessary to shift regulatory authority from the Government to business people to make self-regulation, as a rule, that was born from the agreement of the business actors themselves. Self-regulation is considered more effective in maintaining fair competition, so that the market will be more dynamic, and consumers will be more prosperous.
\end{abstract}

Keywords: Sharing Economy, Disruptive Innovation, Self-Regulation, Fair Competition

JEL Classification Code: D41, K23, O35, O38

\section{Introduction}

Since the fall of the Soviet Union, most countries headed for democracy and directed their economy towards the pendulum of the economic system of liberalism (Fracchiolla, 2018). It happens both explicitly and slowly, or alone and jointly with other countries (Backhouse, 2005). The free market system historically has shown evidence of being able to create economic growth in various countries (Soto, 2000). All the while, it providing opportunities for everyone (business people) to enter the market, offering a more extensive choice of products and services that are increasingly diverse (Friedman \& Friedman, 2013). So that people as consumers with various levels of ability will get their needs and lead them to prosperity. With the support of technological advances supporting the acceleration of extraordinary innovation (Firman et al., 2020), the era of the 4th Industrial Revolution gave birth to a new

${ }^{1}$ First Author and Corresponding Author. Professor, Faculty of Law, Universitas Muhammadiyah Yogyakarta, Indonesia [Postal Address: Jl. Brawijaya, Tamantirto, Kec. Kasihan, Yogyakarta, 55183, Indonesia] Email: muktifajar_umy@yahoo.co.id

(c) Copyright: The Author(s)

This is an Open Access article distributed under the terms of the Creative Commons Attribution Non-Commercial License (https://creativecommons.org/licenses/by-nc/4.0/) which permits unrestricted non-commercial use, distribution, and reproduction in any medium, provided the original work is properly cited. economic system called the sharing economy, with disruptive innovation business model (Munkøe, 2017).

Disruptive innovation is run by start-up businesses such as e-Bay, Airbnb, Uber, Amazon, and so on, with wealth estimated at billions of US dollars (Doni, 2018). Similarly, in Indonesia, there are 2,117 startup companies, such as Bukalapak, GoJek, Daily Social, Kaskus, Tokopedia, Traveloka, and Blibli (Hardjanti, 2019). This business model is proliferating and is starting to shift the traditional business model. Sharing economy provides opportunities and benefits to anyone who wants to share and consolidate their resources. The surge that occurs can be seen in the following table 1 and table 2 (UNCTAD, 2019).

The sharing economy tends to efficient resources by consuming it together and getting more people involved in investing and providing high returns for investors (Sukandar, 2020). Despite that, sharing economy with this disruptive business model gave birth to legal problems. Existing legal norms are paralyzed and disrupt sustainable business models sustaining innovation (Litoh, 2016). The disruptive business model is carried out in a platform that provides digital infrastructure. Consumption of access to information technology can give users freedom from social obligations to ownership. It has fundamentally changed the attitude toward the symbolic power of private ownership into shared consumption. This issue will challenge existing traditional assumptions and social patterns and have disruptive effects in many sectors of the economy (UNCTAD, 2019). 
Table 1: Top 10 global companies, 31 March 2009 (Billions of dollars)

\begin{tabular}{|l|l|l|c|}
\hline Rank & \multicolumn{1}{|c|}{ Company } & \multicolumn{1}{|c|}{ Industry } & Market capitalization \\
\hline 1 & Exxon Mobil & Oil and gas & 237 \\
\hline 2 & Petro China & Oil and gas & 204 \\
\hline 3 & Walmart & Consumer service & 188 \\
\hline 4 & Industrial and Commercial Bank of China & Financials & 175 \\
\hline 5 & China Mobile & Telecommunications & 163 \\
\hline 6 & Microsoft & Technology & 149 \\
\hline 7 & AT and T & Telecommunications & 145 \\
\hline 8 & Johnson and Johnson & Health care & 139 \\
\hline 9 & Royal Dutch Shell & Oil and gas & 138 \\
\hline 10 & Procter and Gamble & Consumer goods & \\
\hline
\end{tabular}

Source: PricewaterhouseCoopers, 2018, Global Top 100 Companies by Market Capitalization: 31 March 2018 Updated (London)

Table 2: Top 10 global companies, 31 March 2018 (Billions of dollars)

\begin{tabular}{|l|l|l|c|}
\hline Rank & \multicolumn{1}{|c|}{ Company } & \multicolumn{1}{c|}{ Industry } \\
\hline 1 & Apple & Technology & 851 \\
\hline 2 & Alphabet & Technology & 719 \\
\hline 3 & Microsoft & Technology & 703 \\
\hline 4 & Amazon.com & Consumer Service & 701 \\
\hline 5 & Tencent Holdings & Technology & 496 \\
\hline 6 & Berkshire Hathaway & Financials & 492 \\
\hline 7 & Alibaba & Consumer Service & 470 \\
\hline 8 & Facebook & Technology & 464 \\
\hline 9 & JPMorgan Chase & Financials & 375 \\
\hline 10 & Johnson and Johnson & Health care & 344 \\
\hline
\end{tabular}

Source: Price Waterhouse Coopers, 2019

As usual, regulation is running behind technological innovation. Governments in various countries are slow to react and make regulations that accommodate this new business model. This business is successful because it is more efficient, and is a favorite of consumers. But, rather than supporting the regulator, they are more concerned with the conditions of the incumbent (Florin, 2015). At least there are a number of legal issues dealing with the disruptive sharing economy system:

First, for countries that embrace the liberal economy, free competition in the market is governed by competition law (Nugroho, 2014). The most common goals of competition law are the integration of internal markets, consumer protection, protection of business actors, freedom of competition, and economic efficiency (Ana \& Raimundas, 2013). But, substantively, competition law regulates the market so that it is not regulated by anyone. Research results show that a disruptive business model does not violate business competition laws. At the same time, this business model cannot be regulated by standard regulations (Fajar et al., 2019). As Schwartz and Einarson (2018) said, "Innovative sharing economy businesses are characterized by their ability to disrupt traditional counterparts industry. The sharing economy has been branded by many as a disruptive force or disruptive innovation" so that it is often thought to lead to unfair competition.

For example, in the case of online transportation, the Indonesian Government has issued five Permenhub, which are deemed not appropriate. Among them lost in the Judicial review because they are considered to hamper the entry of business actors into the market no entry barrier principle. Similarly, the complexity of managing the telecommunications business using Voice over Internet Protocol (VoIP) telephones from application companies 
like Whatsapp Call, IMO, etc., are high, not to mention the hospitality business with room-sharing business such as Airbnb. The same thing is to mess up the modern shopping business with the marketplace platform (Copps, 2005).

The intricate case of this arrangement has also hit many countries in the world, such as the Philippines, Taiwan, the United States, the European Union, Japan, and others (Fajar et al., 2019). Legal problems become a problem because regulators use conventional business perspectives, which are paradigmatically different (Nurmandi et al., 2019). "Law" seems to lose its normative power to regulate innovations that disrupt the market economy.

From the perspective of legal and development theory, the stability and predictability conditions of a policy are needed (Burg, 1977). Stability and predictability require the law to be able to maintain a balance of competing interests and provide clarity of development direction. Without those two things, business actors feel uncomfortable investing (Erman, 1947).

Secondly, the ancient teachings of Adam Smith (1776) seem to be still relevant in free competition (Biggart, 2002). However, this teaching has provided many stories of economic crises because of the boundless greed of business actors (Caldwell \& Driscoll, 2015; Stiglitz, 2003). Regardless, no matter how free the market system, there must be laws as the governing authority as Cicero doctrine "ubi societas ibi ius" which means if there are people, there is the law (Shidarta, 2014). That is why the law must be present in society with all its dynamics.

Third, the presence of sharing economy with its disruptive innovation increasingly marginalizes state law. That sharing economy with disruptive innovation is increasingly in demand by the community, but the market is increasingly out of control (Chua et al., 2019). From the above condition, a question emerges: is state law still necessary in the era of sharing economy that cannot be reached by standard law? This paper will discuss the aforementioned issue in the following sub-studies.

\section{Competition Law in the Era of Sharing Economy: Redefining Capitalism}

In the sharing economy, there is no fundamental difference in principle with other business systems. Each party can enter the market freely by cooperating and sharing resources that are connected through a digital platform and unexpectedly generate disruption (disruptive) to the normal business order (Lee \& Tan, 2019), (Jones, 2014). With the sophistication of smartphone technology, buyer-seller relationships have invaded people's private space as consumers, whispering words, and displaying images that unwittingly influence the decision to buy (Katyal, 2013).
The market paradigm has changed radically. Competition becomes, not just free, but becomes a brutal competition. Of course, norm reformation as a fair competition guideline is needed to adapt to the existing paradigmatic differences in business (Sabden, 2018). This does not philosophically contradict capitalism in an economic system where private actors are allowed to own and control property according to their own interests. Business people are free to compete in the market (laissez-faire principle), to get the best response from the community, but the principle cannot allow the market to work alone without law, without rules (Scott, 2006). This premise shows that laissez-faire must be limited to prevent greed (Stiglitz, 2003).

Regulation must be able to prevent greed without losing the basic principle of freedom to create prosperity. The existence of law is as the guardian of rights and obligations as well as protecting the dominance of the strong over the weak (Undang Undang Nomor 8 Tahun 1999 Perlindungan Konsumen, 1999). While the Government in a free market must guard against monopolistic practices, eliminate fraud that endangers consumers, fulfill supply when there is a shortage, and collect taxes (Scott, 2006).

There are three levels of organized systems in capitalism. First, the market, where the competition takes place; second, institutions such as companies and business people; third, there is an authority that manages the system. The capitalist system evolved and developed effectively with two powers, the first is the invisible hand that is implicit in the price mechanism of supply and demand; and the second is explicitly managed by the Government through the legislature and bureaucracy, in the form of regulations and governance (Scott, 2006).

The Industrial Revolution 4.0 is full of surprises, often even considered dangerous as well as very helpful to the community. But, from a normative perspective, there is a tradition that must be maintained. The law remains an extraordinary tool: able to evolve and adapt. It can always keep up with its traditional "tools" which are considered quite effective in managing new realities when confronted with this technological revolution, although it has always been a debate of economists and legal experts at the contemporary political level: "postulating excessive regulation threatens competitiveness" (Gautrais, 2018). Therefore, free-market law needs to be reformulated in the Industrial Revolution 4.0 era, which gave birth to a disruptive sharing economy (Mayer-Schonberger \& Ramge, 2018).

Gautrais (2018) considers that there has been a legal vacuum without precedent. His opinion is inaccurate because the law is seen as narrowly formalistic, which only comes from the state. Normativity must be understood pluralistically, with interactions between various levels. Such a formal text of the regulation is confronted with the 
company's contract documents through the structure with its own specific settings. With popular thinking, that building legal norms requires a more plural, more global vision so that law becomes an open system to adopt existing social phenomena (Gautrais, 2018).

Many articles indicate legal problems from within the sharing economy system, namely: (1) resource ownership, which is often latent, (2) labor relations (workforce), and (3) the accountability of the parties (Brescia, 2016). While legal problems from outside the system are very diverse, including (1) security and consumer protection, (2) administrative procedures, (3) intellectual property rights, (4) taxation, and even (5) environmental law (Cortez, 2014). The basic concept of market theory postulates the economy consists of individuals who compete. Theoretically, the more traders, the more goods and the more prices are better (Kurien, 2015).

The market is a forum where producers serve consumers. But there is propaganda from external parties, namely, "the State." Because it is accused of over-regulating the market, this is not in accordance with the idea of democracy; in short: "Democracy vs Totalitarianism." In the context of a democratic state, "the State" should say about the economy: "Leave it to the Market" (Kurien, 2015).

The market will continue to be dynamic as long as there is a movement of ideas and innovation. As Milton Friedman said: "The role of people is to keep ideas alive until a crisis occurs" (Alkire \& Ritchie, 2012). The market will be good if innovative products emerge. To maintain fair competition, business competition law is needed so that the market remains free, and there is no cheating and monopoly. The problem, raison d'être from the law, is regulation. However, the purpose of competition law is sometimes not explicitly stated in the law or guidelines. This has led to a debate about the regulation of the sharing economy, which is disruptive by default (Lee et al., 2015).

The concept of harmonizing the law is strived to be synchronous and convergent. Until now, every country still faces a paradigmatic problem regarding the sharing economy (Kliemann, 2002). The same situation occurred when there was legal turmoil dealing with the Internet several decades ago. Many problems arise, such as the validity of digital data as evidence, the mechanism of the agreement that is carried out online, and the birth of digital signatures (Fajar, 2001). At that time, the experts were looking for a basic philosophy and legal theory from evidence and signatures, which were then applied in the electronic protocol (Makarim, 2003).

Philosophically, the choice of an economic system that is fundamentally adhered to has no clarity. Business actors, even the state, determine it because of the importance of speed to be fulfilled needs. This means that any economic system is only pragmatic in order to have a goal of good and momentary benefit (Kronman, 1998). The sharing economy system has been present in the economic activities of people in almost all countries brings various problems for policymakers. The sharing economy "has been on an exponential growth curve over the last couple of years and has been the subject of considerable interest to the stakeholders and policymakers across the globe."

Many experts argue that sharing economy is identical to collaborative consumption (Nguyen \& Llosa, 2018). This fact significantly reduces transaction costs. This business minimizes traditional business processes like sharing spare rooms Airbnb or empty vehicles Grab, Gojek, Uber, also a market place model that sells products or services for those who do not have outlets Bukalapak, Tokopedia, Amazon, etc (Litoh, 2016).

The sharing economy also changes the legal relationship between the parties because they need each other. There are no more laborers and employers, but partnerships. The power of ownership capital has shifted to the power of sharing resources, such as exchanges, collective purchases, collaborative consumption, shared ownership, shared values, cooperatives, redistribution, peer-to-peer, collaborative economics, microfinance, etc. (Skjelvik et al., 2017). This system builds any market to unite a network of individuals that are distributed to share or exchange assets. This business includes all types of goods and services that are shared or exchanged (Chairwoman et al., 2016). So sharing economy is a dynamic and effective example for competition and prevents monopoly from one of the big capital owners (Dunne, 2018).

But the question arises whether sharing economy has an impact on welfare for the community. Welfare comes from the words well and fare, meaning that the costs are still affordable (Greve, 2008). The word welfare has historically been associated with happiness and prosperity (Williams, 2014). The author elaborates from various definitions that welfare is a condition of individuals and society with all levels of economic ability that is guaranteed to be able to get all the necessities of life so that they are free from anxiety and achieve happiness.

Because sharing economy runs efficiently and inclusive, this results in: (1) for consumers to access all needs based on the purchasing power of each economic strata of society; (2) for businesses open a way to enter the market without obstacles with the ability of capital or resources they have. This business brings new products, assets, and suppliers to the market give all business actors (unconditional) opportunities to enter the market flexibly and expand the market size (Dunne, 2018).

This pattern is different from the way conglomerates accumulate capital because sharing fundamentally changes the way of consumption and distribution (Fajrina, 2016). Khasali (2018) said that sharing economy is the attitude 
of participation in economic activities that create value, independence, and prosperity. All of them perform their respective roles and share the results, so it is role sharing and result sharing (Fajrina, 2016).

Welfare will be easily achieved as long as legal regulations are not an obstacle by minimizing various licensing procedures that cause additional costs. Efficiency must always be relevant to policy. The legal effect must also be followed by the importance of the value of income distribution, and the sharing economy provides opportunities for the distribution of assets and income (Cooter, 2000).

\section{The Concept of Sharing Economy Regulation with a Disruptive Business Model}

Disruptive innovation explains why leading companies often fail to remain at the top of the industry when technology or markets change (Bower \& Christensen, 1995). The results clarify that in hundreds of enterprises or profit-oriented institutions have been replaced by more creative newcomers.

Schmidt and Druehl make the difference between two types of technological innovation, sustaining innovation, and disruptive innovation (Schmidt \& Druehl, 2008). Sustaining innovation is usually carried out by large companies, whereas disruptive innovation is generally carried out by a start-up company (Morris, 2013).

Disruptive innovation triggers a controversial political and market response (de Streel \& Larouche, 2015). Technology is developing fast, and markets are growing more integrated, driven by artificial intelligence. Innovation "jumped" unexpectedly that was previously unimaginable, and resulted in a great shifting (Khasali, 2018). The impact is very pleasing to the consumer world, but it is not known to what extent it continues.

The role of the court and regulator is significant to anticipate this chaos (Kolacz \& Quintavalla, 2019). Because it contains potential hazards, such as the invasion of privacy, violation of intellectual property rights, taxation, and the issue of responsibility around this technology, and the law must be able to fill this gap.

The inherent characteristics and adverse risks of this business are: (1) increasing competition, by attracting customers from conventional providers; (2) displacing conventional businesses out of the market; (3) platform companies offer intermediation services that allow exchanges between partners to have significant implications for violations of competition law; and, (4) often conflict with regulatory regimes that control, and trigger criticism that such competition is inherently "unfair" due to asymmetry with conventional business models (Dunne, 2018).

The challenge for regulators and legal experts is to make the right rules, but they cannot negate good innovation while the challenge for companies is to have to accept legal products from regulators in protecting the public (Schmitt, 2017). The legal field has moved further than anyone thought.

Nobody expected Uber and Airbnb to become billions of household businesses. Siger said, "only two or three years ago, there were open questions whether ride-sharing and room-sharing had the right to exist?" In fact, everyone agrees that the sharing economy, even if it is disruptive, must be maintained, because it provides convenience, affordability, the benefit of assets, and mutual prosperity. Existing government regulations have become obsolete to apply to this new industry. So we need a forward-looking regulatory approach.

Steel and Larouche stated that competition law enforcement must adjust methods to handle and protect the innovation process by adjusting existing legal principles. The regulation must call for a change: from static efficiency and price evolution to the dynamic efficiency and innovation incentives. For this reason, it is necessary to redefine markets, business behaviour, and violation theories (Alexandre de \& Pierre, 2015).

Conceptually the idea was born with a different way of thinking, even though it did not conflict. So we need innovative legal logic as well, in providing unexpected new standards of legal norms (Alexandre de \& Pierre, 2015). Miller proposed several basic principles to regulate the sharing economy, including: (1) sharing economy requires a different regulatory response outside of traditional rules; (2) sharing economy must be strictly regulated; (3) sharing economy is a real and good thing; (4) sharing economy builds new markets and takes over existing markets; and (5) sharing economy must respond to all parties in developing regulations (Miller, 2016). The author believes that some fundamental issues must be considered to regulate the sharing economy that disrupts the normal and standard legal order.

First, the law and its experts must accept the reality of this changing era as a fact of natural selection. Where naturally the new one will replace the old one. All of this is not a form of injustice or cruelty of competition, but a natural process. Like the teachings of Heraclitus: nothing endures, but change. Even Schwab said that dealing with dramatic and profound changes in the industrial revolution 4.0, would demand all social institutions to redefine and reshape themselves (Tariga, 2018). Likewise, legal institutions must reform and redefine themselves to continue to exist as a means of social control in a rapidly changing environment.

Second, business law dealing with innovations in highly dynamic economic activities must reformulate a system that has been "inviolable". Philosophically, the law is more effective if it is developed based on pragmatism. The law must see the truth from the practical side due to its good and usefulness (Posner, 2003). In line with Holmes' dictum: “The 
Life of law has not been logic; it has been experienced." It implies that the law must develop because of the influence of empirical reality, although it is often not suitable to be applied in a country that adopts a civil law legal system, which further predominates Kalsenian Theory, where the law is built on a grund norm (Hurst, 1964).

From this the two legal systems can be combined to be able to regulate innovative business models, with the condition that: (1) pragmatism as the basis for legal development must not be in conflict with grund norms, and; (2) more specifically, business law that regulates economic activities, such pragmatism must be able to provide goodness and benefit so as to create social justice or prosperity for the whole community.

Third, the legal authority must be reconstructed, which was once absolutely the domain of the state, must begin to be partly shifted to the market authority. However, there are still many criticisms of market power that defend large capital owners and marginalize small business actors. In this era of sharing economy, this paradigm must be reviewed, because this era no longer puts the power of capital ownership to control the market. The power of ownership has been replaced by the power of community-based sharing resources. It is similar to the economic thinking of Sukarno's Marhaenism or Hatta's Koperasi, where the owners of small capital work together (Mukoyimah, 2018). This concept also shows that shared ownership does not lead to economic or environmental disasters (Arthurs, 2018).

This fact makes the basis that the law can be regulated by market participants themselves (self-regulation) through the social contract of the parties involved. This social agreement is the basis for the formation of associations that have free power to regulate and defend their interests and are obeyed by their members because freedom is vital to move the community towards the intended goal. As Locke said, perfect freedom and equality that direct people to achieve the best life they want to regulate themselves for what they have. This is a natural law that instructs everyone not to harm others. In social contracts, every person gets protection from the Government in charge of upholding the law and adjudicating law violations (Ogus et al., 2011). That is, as long as freedom occurs in the market, let them regulate based on mutual agreement in the form of self-regulation. The presence of the Government is needed when violations and crime happen in the market.

Self-regulation becomes an alternative solution to the chaos of norms that come from government authorities to regulate the sharing economy. The concept of self-regulation is understood as a law formulated by private institutions to regulate professional activities and trade (Ogus et al., 2011). This regulatory model is considered capable of maintaining economic benefits and is open to innovation and the dynamic Internet industry in the future. Despite that, self-regulation requires effective public control, especially from consumers (Marsh, 2009). Several studies have shown that self-regulation is more effective because business people are more aware of what is regulated based on the interests and participation of the public as consumers (Grajzl \& Murrell, 2007).

The self-regulation model has been used in Indonesia. For example, in the regulation of Corporate Social Responsibility in Law No. 40 of 2007 concerning Limited Liability Companies and Law No. 25 of 2007 on Investment because the Government does not provide detailed guidance on how to implement it. So that the company governs itself, and this is also done in several countries (Scheltema, 2016).

Self-regulation is based on Reflexive Law Theory, which explains the limitations of government law (limit of law) in regulating a complex society. This legal theory allows private actors, such as corporations, to regulate themselves freely (Fajar, 2010, 2018). This theory is to overcome the crisis of the interventionist state from the inability of the law to meet the demands of various changing community problems (Elms \& Westermann-Behaylo, 2012). The same thing applies when the law is dealing with a disruptive sharing economy.

The idea of self-regulation leaves a question where the position of Government as the holder of power regulates. According to the author, the Government's position in the free competition is needed as a guardian and law enforcer when: (1) there is fraud and unfair competition in the free market; (2) preventing monopolistic practices; (3) protecting the public as consumers of dangerous products; (4) sufficient if a product scarcity occurs; (5) providing social protection and security for the disadvantaged; and (6) collect taxes from each transaction and then return it in the form of providing market development infrastructure and providing public facilities.

\section{Conclusion}

The sharing economy gives birth to disruptive innovation that may create chaos if it is regulated by norms that are used to regulate conventional business. As a result, it requires several legal breakthroughs; for example, business law must be designed pragmatically in order to oversee changes in business models that are rapidly changing. For this reason, it is necessary to shift regulatory authority from the Government to business people by giving them the right to make self-regulation, as a rule, that was born from the agreement of the business actors themselves. This will be more effective in maintaining fair competition, and the market will be more dynamic so that people as consumers will benefit more and be more prosperous.

\section{References}

Alexandre, S., \& Pierre, L. (2015). Directorate For Financial And Enterprise Affairs Competition Committee Global Forum On 
Competition Disruptive Innovation And Competition Policy Enforcement. Retrieved from www.oecd.org/competition/ globalforum

Alkire, S., \& Ritchie, A. (2012). Winning Ideas: Lessons from Free Market Economics. SSRN Electronic Journal. https://doi. org/10.2139/ssrn.1815256

Ana, N., \& Raimundas, M. (2013). Some Thoughts Concerning the Main Goals of Competition Law. Jurisprudencija, 20(2), 627642.

Arthurs, H. (2018). The False Promise of the Sharing Economy. In: Law and the "Sharing Economy" (pp. 55-72). https://doi. org/10.2307/j.ctv5vdczv.6

Backhouse, R. . (2005). The rise of free market economics: economists and the role of the state since 1970. History of Political Economy, 37(5), 355-392.

Biggart, N. W. (2002). Readings in Economic Sociology. In: N. W. Biggart (Ed.), Readings in Economic Sociology. https://doi. org/10.1002/9780470755679

Bower, J. L., \& Christensen, C. M. (1995). Disruptive Technologies: Catching the Wave. Harvard Business Review, 73(1), 43-53.

Brescia, R. H. (2016). Regulating the Sharing Economy: New and Old Insights into an Oversight Regime for the Peer-toPeer Economy. Nebraska Law Review, 95. Retrieved from https://heinonline.org/HOL/Page?handle=hein.journals/ nebklr95\&id $=93 \&$ div $=\&$ collection $=$

Burg, E. M. (1977). Law and Development: A Review of the Literature \& a Critique of "Scholars in Self-Estrangement." The American Journal of Comparative Law, 25(3), 492. https:// doi.org/10.2307/839691

Caldwell, J., \& Driscoll, T. O. (2015). What caused the great depression? In socialstudies.org. Retrieved from https://www. socialstudies.org/system/files/publications/articles/se_710270. pdf

Chairwoman, E. R., Ohlhausen, M. K., Mcsweeny, T. P., Lao, M., Koslov, T. I., Stivers, A. E., ... Goshorn, J. A. (2016). The "Sharing" Economy Issues Facing Platforms, Participants \& Regulators A Federal Trade Commission Staff Report Workshop Team and Report Contributors.

Chua, E. L., Chiu, J. L., \& Bool, N. C. (2019). Sharing Economy: An Analysis of Airbnb Business Model and the Factors that Influence Consumer Adoption. Review of Integrative Business and Economics Research, 8(2).

Cooter, R. (2000). Law \& Economics (6th ed.). Boston, MA: Addison-Wesley.

Copps, M. J. (2005). Disruptive Technology ... Disruptive Regulation. Michigan State Law Review, 2005. Retrieved from https://heinonline.org/HOL/Page?handle=hein.journals/ mslr2005\&id $=321 \&$ div $=\&$ collection $=$

Cortez, N. (2014). Regulating Disruptive Innovation. Berkeley Technology Law Journal, 29. Retrieved from https://heinonline.org/HOL/Page?handle=hein.journals/ berktech29\&id $=185 \&$ div $=\&$ collection $=$ de Streel, A., \& Larouche, P. (2015). Disruptive Innovation and Competition Law Enforcement. SSRN Electronic Journal. https://doi.org/10.2139/ssrn.2678890

Doni, W. (2018). Legal in Start Up Bussiness. In: Metagraf. Solo.

Dunne, N. (2018). Competition Law (and Its Limits) in the Sharing Economy. Retrieved June 24, 2020, from SSRN Electronic Journal website: https://papers.ssrn.com/sol3/papers. cfm?abstract_id=3058697

Elms, H., \& Westermann-Behaylo, M. (2012). Corporate Social Responsibility. Socially Responsible Finance and Investing: Financial Institutions, Corporations, Investors, and Activists, 3(1), 39-54. https://doi.org/10.1002/9781118524015.ch3

Erman, R. (1947). The Role of Law in Development in the Era of Globalization Implications for Legal Education in Indonesia. Jakarta, Indonesia.

Fajar, M. (2001). Electronic Commerce in Indonesian Legal Perspective. Jakarta, Indonesia

Fajar, M. (2010). Corporate Social Responsibility: A Study on the Implementation of CSR Provisions in Multinational, National Private \& BUMN Companies in Indonesia. Yogyakarta, Indonesia: Pustaka Pelajar.

Fajar, M. (2018). Corporate Social Responsibility in Indonesia: Regulation and Implementation Issues. In: Journal of Legal, Ethical and Regulatory Issues (Vol. 21).

Fajar, M., Zwerenz, D., \& Setianingrum, R. B. (2019). Disruptive Innovation on Competition Law: Regulation Issues of Online Transportation in Indonesia. European Journal of Economics and Business Studies, 5(2), 23. https://doi.org/10.26417/ejes. v5i2.p23-37

Fajrina, H. N. (2016, March 29). Sharing Economy, Berbagi Aset dan Keuntungan. CNN.Com. Retrieved from https://www. cnnindonesia.com/teknologi/20160329152224-185-120288/ sharing-economy-berbagi-aset-dan-keuntungan

Firman, A., Putra, A. H. P. K., Mustapa, Z., Ilyas, G. B., \& Karim, K. (2020). Re-conceptualization of Business Model for Marketing Nowadays: Theory and Implications. Journal of Asian Finance, Economics and Business, 7(7), 279-291. https:// doi.org/10.13106/jafeb.2020.vol7.no7.279

Florin, Z. (2015). Creative Destruction and the Sharing Economy. Science Bussiness. Retrieved from https://books.google. co.id/books?hl=en\&lr=\&id=mavfDQAAQBAJ \&oi=fnd\&p$\mathrm{g}=\mathrm{PR} 1 \& \mathrm{dq}=$ The + Sharing + Economy $+\mathrm{Is}+$ Bringing + Disruptive + Innovation + to + Europe. $+\&$ ots $=9$ IRUBvYaL0\&sig=07mH_Nf m54CuNDNkHBg2_sxAikE\&redir_esc $=y \# v=$ onepàge $\& \mathrm{q} \& \mathrm{f}=$ false

Friedman, M., \& Friedman, R. (2013). Free to Choose: A Personal Statement. In: Pustaka Pelajar. Yogyakarta, Indonesia.

Gautrais, V. (2018). The Normative Ecology of Disruptive Technology. In: Law and the Sharing Economy.

Grajzl, P., \& Murrell, P. (2007). Allocating lawmaking powers: Selfregulation vs government regulation. Journal of Comparative 
Economics, 35, 520-545. https://doi.org/10.1016/j.jce.2007.01. 001

Greve, B. (2008). What is Welfare? Central European Journal of Public Policy, 2(1), 50-73.

Hardjanti, R. (2019). Daftar Peringkat 15 Startup Indonesia, Bukalapak Nomor 1. Okezone.Com. Retrieved from https:// economy.okezone.com/read/2019/06/25/320/2070595/daftarperingkat-15-startup-indonesia-bukalapak-nomor-1

Hurst, J. W. (1964). Justice Holmes on Legal History. New York, NY: Macmillan.

Jones, M. (2014). Territory, politics, and relational autonomy. Territory, Politics, Governance, 2, 109-114. https://doi.org/10. 1080/21622671.2014.927286

Katyal, N. (2013). Disruptive Technologies and the Law. Georgetown Law Journal, 102. Retrieved from https:// heinonline.org/HOL/Page?handle=hein.journals $/$ glj $102 \&$ id $=1741 \&$ div $=\&$ collection $=$

Khasali, R. (2018). The Great Shifting. Retrieved from https://books. google.co.id/books? $\mathrm{hl}=$ en\&lr=\&id=uMdsDwAAQBAJ\&oi=fnd\&pg=PP1\& dq=Khasali,+Rhenald.(2018).+ The+Great + Shifting.+Jakarta:+Gramedia\&ots $=$ Gb_NRErvNj\&sig $=\mathrm{m} 9$ m9g4NFSW4RHn34mzxL5b1Me8c7Y\& redir_esc $=\mathrm{y} \# \mathrm{v}=$ onepage\&q=Khasali\%2C Rhenald.(2018). The Great Shifting

Kliemann, A. (2002). Framework for producer organisations in the milk sector - The relationship of agriculture and competiton law. In DG AGRI, Unit G1-Governance of Agri-Food Markets. https://doi.org/10.2307/840879

Kolacz, M. K., \& Quintavalla, A. (2019). Law in the Face of Disruptive Technology, An Introduction. European Journal of Risk Regulation, 10(1), 1-3. https://doi.org/10.1017/ ERR.2019.23

Kronman, A. T. (1998). The Value of Moral Philosophy. Harvard Law Review, 111(7), 1751. https://doi.org/10.2307/1342480

Kurien, C. T. (2015). The Market Economy: Theory, Ideology and Reality. Review of Development and Change, 20(1), 3-22. https://doi.org/10.1177/0972266120150101

Lee, C., Lee, \& Cassey. (2015). The Objectives of Competition Law. Retrieved from https://econpapers.repec.org/RePEc: era:wpaper:dp-2015-54

Lee, J. W., \& Tan, W. N. (2019). Global Corporate Citizenship: Cross-cultural Comparison of Best Practices in the Global Automotive Industry. Journal of Asian Finance, Economics and Business, 6(1), 261-271. https://doi.org/10.13106/jafeb.2019. vol6.no1.261

Litoh, H. (2016). Disruptive Innovation: Implications for Enforcement of Competition Law. Retrieved from www.ccs. gov.sg

Makarim, E. (2003). Compilation of Telematic Laws. Jakarta, Indonesia: PT. Raja Grafindo Persada.

Marsh Jr., R. M. (2009). Legislation for Effective Self-Regulation: A New Approach to Protecting Personal Privacy on the Internet. Michigan Telecommunications and Technology Law Review, 15(2), 543-563.
Mayer-Schonberger, V., \& Ramge, T. (2018). A Big Choice for Big Tech: Share Data or Suffer the Consequences. Foreign Affairs, 97. Retrieved from https://heinonline.org/HOL/ Page?handle $=$ hein.journals/fora97\&id $=888 \&$ div $=\&$ collection $=$

Miller, S. R. (2016). First Principles for Regulating the Sharing Economy. Harvard Journal on Legislation, 53. Retrieved from https://heinonline.org/HOL/Page?handle=hein.journals/ hj153\&id $=151 \& \operatorname{div}=\&$ collection $=$

Mukoyimah. (2018). Rhetoric in Soekarno's Speech on Guided Democracy. In: Jurnal Komunikasi Dan Penytiaran Islam.

Munkøe, M. M. (2017). Regulating the European Sharing Econom-y: State of Play and Challenges. Intereconomics, 52(1), 38-44. https://doi.org/10.1007/S10272-017-0641-3

Nguyen, S., \& Llosa, S. (2018). On the difficulty to define the Sharing Economy and Collaborative Consumption-Literature review and proposing a different approach with the introduction of'Collaborative Services.

Nugroho, S. A. (2014). Business competition law in Indonesia. Yogyakarta, Indonesi:a Prenada Media.

Nurmandi, A., Mutiarin, D., Jovita, H., Fajar, M., \& Yao, N. L. (2019). Digital Policy, Regulation and Governance. Emerald Insights Publisher, 21(2).

Ogus, A., Carbonara, E., Ogus, A., \& Carbonara, E. (2011). Selfregulation. Retrieved from https://econpapers.repec.org/RePEc: elg:eechap:13221_13

Sabden, O. (2018). The Concept of the Future and the New Paradigm of the Fifth Spiral: State, Business, Science, Society and Informatization. Journal of Asian Finance, Economics and Business, 5(4), 173-185. http://doi.org/10.13106/jafeb.2018. vol5.no4.173

Scheltema, M. (2016). Balancing Public and Private Regulation. In: Utrecht Law Review.

Schmidt, G. M., \& Druehl, C. T. (2008). When is a disruptive innovation disruptive? Journal of Product Innovation Management, 25(4), 347-369. https://doi.org/10.1111/j.15405885.2008.00306.x

Schmitt, R. (2017). The Sharing Economy: Can the Law Keep Pace with Innovation? - Cover Story - Stanford Lawyer Magazine - Stanford Law School. Law.Stanford.Edu. Retrieved from https://aw.stanford.edu/stanford-lawyer/articles/the-sharingeconomy-can-the-law-keep-pace-with-innovation/

Schwartz, B. P., \& Einarson, E. (2018). The Disruptive Force of the Sharing Economy. Asper Review of International Business and Trade Law, 18. Retrieved from https:// heinonline.org/HOL/Page?handle=hein.journals/ asperv18\&id $=231 \&$ div $=\&$ collection $=$

Shidarta. (2014). Desiderata of Law. Retrieved from https:// business-law.binus.ac.id/2014/10/24/desiderata-hukum/

Skjelvik, J. M., Erlandsen, A. M., \& Haavardsholm, O. (2017). Environmental Impacts and Potential of the Sharing Economy. Nordic Council of Ministers.

Soto, H. (2000). The mystery of capital: rahasia kejayaan kapitalisme barat. In: Penerbit Alam. 
Stiglitz, J. E. (2003). Greed iIn The 90s and The Beginning of The World Economic Crisis: Left Margin. Tangerang Selatan, Indonesia: Cipta Lintas Wacana.

Sukandar, C. A. (2020, June 24). What is the Sharing Economy? Wartaekonomi.Co.Id. Retrieved from https://www. wartaekonomi.co.id/read227570/apa-itu-sharing-economy. html
UNCTAD. (2019). Intergovernmental Group of Experts on Competition Law and Policy, eighteenth session. Retrieved from https://unctad.org/en/pages/MeetingDetails. aspx?meetingid $=1895$

Williams, R. (2014). A vocabulary of culture and society. Oxford, UK: Oxford University Press. 